Original Article

\title{
The Use of Spirituality in Narrative Couples and Family Therapy
}

\author{
Zehranur Akbulut ${ }^{1}$ \\ Istanbul Sabahattin Zaim University
}

${ }^{1}$ Istanbul Sabahattin Zaim University, Faculty of Education, Department of Psychological Counseling and Guidance, Istanbul, Turkey. E-mail: zehranur.akbulut@izu.edu.tr

\author{
Corresponding author: \\ Zehranur Akbulut \\ E-mail: \\ zehranur.akbulut@izu.edu.tr
}

eISSN: $2458-9675$

\section{Received Revision:}

13.11.2019

Revision:

18.01.2020

Accepted:

12.02.2020

(C) Copyright 2020

by Author(s)

\begin{abstract}
Narrative therapy is a postmodern therapy approach that suggests that people make sense of their lives through the stories they create. Spirituality plays an active role in the processes of understanding life as a part of the stories of spiritually oriented individuals, couples, and families. The nature of narrative therapy aimed at considering the culture, beliefs, and spiritual values that shape clients' stories allows spiritually oriented couples and families to express the spiritual dimension they possess within the therapy process of this approach and to use spirituality as a source of power for dealing with problems. This study aims to discuss narrative couples/family therapy and the use of this therapy method within the framework of the related literature by noting ethical rules and incorporating spirituality with spiritually oriented couples and families. Information is provided in this context primarily with regard to narrative therapy, narrative couples/family therapy, the process of narrative couples/family therapy, and the responsibilities of the therapist in this therapy approach. Afterward, case samples in narrative therapy with regard to the importance of spirituality are presented, and the use of spirituality by inclusion in the techniques is explained using narrative couples/family therapy techniques. This study is thought to fill in the missing points that exist with in Turkey's literature with regard to both narrative couples/family therapy as well as the use of spirituality by incorporating it in family therapy and to provide a diff erent viewpoint to practitioners and researchers in the field.
\end{abstract}

Keywords: Spirituality $\bullet$ Family Therapy $\bullet$ Couples Therapy $\bullet$ Narrative Therapy $\bullet$ Narrative Couples and Family Therapy

\section{Narrative Çift ve Aile Terapisinde Maneviyatın Kullanımı}

\section{$\ddot{O} \mathbf{z}$}

Naratif terapi, insanların hayatlarını oluşturdukları hikayeler aracılığıyla anlamlandırdığını öne süren postmodern bir terapi yaklaşımıdır. Maneviyat, manevi yönelimli bireylerin, çiftlerin ve ailelerin hikayelerinin bir parçası olarak yaşamı anlamlandırma süreçlerinde etkin bir rol oynamaktadır. Naratif terapinin; danışanların hikayelerini şekillendiren kültür, inanç ve manevi değerleri göz önüne almaya yönelik doğası, bu yaklaşımın manevi yönelimli çift ve ailelerin sahip oldukları manevi boyutu terapi süreci içerisinde dile getirmelerine ve maneviyatı sorunlarla baș etmede bir güç kaynağı olarak kullanmalarına imkan sağlamaktadır. Bu çalıșmada naratif çift/aile terapisinin ve bu terapi yönteminin etik kurallar dikkate alınarak manevi yönelimli çift ve ailelerle maneviyat dahil edilerek kullanımının ilgili literatür çerçevesinde ele alınması amaçlanmaktadır. Bu kapsamda öncelikle naratif terapiye, naratif çift/aile terapisine, naratif çift/aile terapisi sürecine ve bu terapi yaklaşımında terapistin sorumluluklarına ilişkin bilgi verilmektedir. Sonrasında naratif terapide maneviyatın önemine değinilerek vaka örneği sunulmakta ve naratif çift/aile terapisi teknikleri ile tekniklere maneviyatın dahil edilerek kullanımı açıklanmaktadır. Bu çalışmanın yurt içi alanyazında hem naratif çift ve aile terapisine yönelik hem de maneviyatın naratif çift ve aile terapisine dahil edilerek kullanılmasına yönelik var olan eksik noktaları tamamlayacağı, alandaki uygulayıcılara ve araştırmalara farklı bir bakış açısı sağlayacağı düşünülmektedir.

Anahtar Kelimeler: Maneviyat • Aile Terapisi $\bullet$ Çift Terapisi $\bullet$ Naratif Terapi $\bullet$ Öyküsel Terapi • Naratif Çift ve Aile Terapisi

Citation: Akbulut, Z. (2020). The use of spirituality in narrative couples and family therapy. Spiritual Psychology and Counseling, 5, 113 - 130. https://dx.doi.org/10.37898/spc.2020.5.1.099 


\section{An Overview of Narrative Therapy}

Narrative therapy, which is the meaning constructed on the point of focus over language and discourses, is known as the fourth wave/force in the field of psychotherapy (Payne, 2006). Narrative therapy emerged in the 1980s as an applicable form of the social constructivist approach, which has postmodernist foundations. In the social constructivist approach, people are considered to play an active role in constructing knowledge and truth (DeMille \& Montgomery, 2016; Suddeath, Kerwin, \& Dugger, 2017). The Australian Michael White and the New Zealander David Epston (1990) introduced narrative therapy in their book Narrative Means to Therapeutic Ends.

According to narrative therapy, people are born into the world of written stories and very rarely become aware of these stories. People load meaning onto the events they experience by sorting them one after another and creating a narrative theme with time. The objects required for a story to form are events, succession (sequencing, connections), time, content (meaning, context), or themes. The individual lives one's life through the narrations one forms about oneself and the stories others tell about themself. Meaning is the abstract idea of these stories. Individuals constantly add meaning to their experiences. From this perspective, people are both the scene authors of their own stories as well as the leading actors (Brown \& Augusta-Scott, 2007; Freedman \& Combs, 1996; Morgan, 2000; White, 2007; Yeni, 2014).

The created stories later turn into absolute truths for the individual's life. The stories cover topics such as who are we, where do we come from, what do we do, and what do we think about what we experience (Crocket, 2013). Social impacts, family structure, child-raising patterns, interpersonal interactions, historical times, culture, religion, sub-identities, group needs, and economic reasons form the individual's life story in narrative therapy (Karairmak \& Bugay, 2016).

As a result of one's interactions with the environment, the individual can add undesired rings to the story that limit the individual. These rings that emerge as a result of social interactions start to dominate the original story after a certain period of time (Neukrug, 2011, as cited in Terzi \& Tekinalp, 2013). Because the expressions of the dominant culture are very strong, individuals internalize the messages of the dominant discourse and of the identities they've acquired with respect to the situations they experience as their own realities (White, 1992).

People feel the need for psychological counseling when they consider their own stories to be meaningless or their personal experiences to be incompatible with their stories. From this perspective, the aim of narrative therapy is to demolish the negative structure of one's own story and to bring about an alternative reconstructed narrative (Freedman \& Combs, 1996; White \& Epston, 1990). 


\section{Narrative Couples and Family Therapy}

Family therapy is a therapy method that concentrates on areas such as increasing or facilitating verbal and emotional communications that lead to harmony among family members; restoring the balance of power in the family; assisting in solving acute problems the family faces such divorce, death, suicide attempts, or being fired from work; and preventing accusations directed at the chosen individual (Samanc1 \& Ekici, 1998). Couples therapy is defined as an organized psychological aid for changing the interactions of two people who are in conflict with one another (Akdemir, Karaoğlan, \& Karakaş, 2006).

Narrative therapy comes from within the family therapy tradition through the influence of the Palo Alto school, which transfers the focus from the family structure to the meanings and interpretations that the client gives to life events (Polkinghorne, 2000). Families are believed to create, maintain, and transform their lives by way of the stories they share in narrative family therapy. The purpose in the therapy is to increase cooperation among family members by externalizing the family's problems and enabling movement for problem solving and alternative stories. No pattern needing to be reached is found in narrative family therapy that is valid for all families. Families are encouraged to struggle in common against the externalized problem, use resources, and configure a new family story together by joining forces as a team (Freedman, 2014; Gladding, 2012).

Narrative family therapy aims to allow family members to discover the thoughts they choose about events, situations, and relationships; to reveal the hidden aspects located within their chosen thoughts in relational, emotional, and psychological terms; and to encourage reflecting upon the different ideas produced in the family from their various perspectives (Fredman, 1997, as cited in Vetere \& Dowling, 2016). Narrative couples therapy works on couples forming new alternative stories in their lives by having them gain a point of view beyond the couple's dominant stories. The goal is to have couples develop the stories they choose and help them live these stories. In this context, value is given to each couple's unique story (Freedman \& Combs, 2008).

Much research has been performed with the aim of testing the effectiveness of narrative couples and family therapy. When examining the performed research, this therapy method is found to have positively contributed to solving the problems of couples affected by infidelity (Duba, Kindsvatter, \& Lara, 2008); couples or families who've been adopted (Gold, 2016); families who describe having a lesbian, gay, or bisexual child (Saltzburg, 2007); homeless families (Fraenkel, Hameline, \& Shannon, 2009); families where intense parent-child conflicts are experienced (Besa, 1994); new families formed by newly married individuals (Madigan, 2016), and spiritually oriented families (Morningstar, 2010). When examining the literature outside of 
Turkey, the inclusion of spiritual elements in narrative therapy are additionally seen to be used while working with spiritually oriented clients; studies are also found to reveal narrative therapy that is used by including spiritual elements to have a positive impact on solving the problems of spiritually oriented individuals, couples, and families (Baldwin \& Estey, 2015; Bermúdez \& Bermúdez, 2002; De Beer \& Müller, 2009; McNicholas, 2018; McWeigh, 2016). When examining the literature in Turkey, however, no study is seen related to the use of spirituality in narrative couples/family therapy, and the theoretical knowledge and research on narrative couples/family therapy is seen to be limited. From this perspective, the fact that this study aims to explain the use of the narrative couples/family therapy approach where spiritual elements are included for spiritually oriented clients is believed to fill a significant gap in the literature. In this scope, the study provides information on the process of this therapy approach and its use by including spirituality after an explanation is made about narrative couples and family therapy.

\section{The Process of Narrative Couples and Family Therapy}

Before beginning the process of narrative couples and family therapy, the therapist needs to inform the couple/family and convey to them the consultation rules at the start of the session. The therapist should provide information with regard to the therapist establishing balance between spouses/among family members and their being treated equally by the therapist. The therapist should explain that sometimes spouses/family members will be received together in sessions, and sometimes separate sessions will be made with spouses/family members. Additionally therapists should provide information

Table 1.

The Narrative Couples and Family Therapy Process (Carr, 1998; Freedman \& Combs, 2008)

\begin{tabular}{ll}
\hline The Collaborative & The therapist is situated not as the expert but as the observer in the therapy process. \\
Approach & The client and therapist are in cooperation regarding producing a solution to the \\
problem and developing new narratives and identities. The therapist is sensitive \\
to culture and pays attention to the language the clients use. Clients are asked \\
questions from a multi-faceted point of view, but the focus is on listening rather \\
than asking questions.
\end{tabular}

\begin{tabular}{ll}
$\begin{array}{l}\text { Externalizing the } \\
\text { Problem }\end{array}$ & $\begin{array}{l}\text { Clients are assisted in considering the problem as an entity independent of the self } \\
\text { in this process. The therapist and couple/family members are in unity against the } \\
\text { externalized problem. }\end{array}$ \\
\hline $\begin{array}{l}\text { Searching for } \\
\text { Alternative Results and } \\
\text { Comments }\end{array}$ & $\begin{array}{l}\text { The therapist assists in determining the times when the couple/family members are } \\
\text { not suppressed by the problem and in creating the narratives they want to possess. }\end{array}$ \\
\hline $\begin{array}{l}\text { Focusing on the New } \\
\text { Narrative }\end{array}$ & $\begin{array}{l}\text { The couple/family members are asked questions with regard to determining details } \\
\text { related to the alternative narrative. }\end{array}$ \\
\hline $\begin{array}{l}\text { Establishing the Link } \\
\text { Between Past and } \\
\text { Present }\end{array}$ & $\begin{array}{l}\text { The connection is established with significant past experiences, the new narrative } \\
\text { is carried to the future, and the couple/family members are assisted in forming the } \\
\text { alternative new story they prefer. }\end{array}$ \\
\hline $\begin{array}{l}\text { Inviting a Witness/ } \\
\text { Outside Observer }\end{array}$ & $\begin{array}{l}\text { Significant people in the lives of the couple/family members or a couple or family } \\
\text { who received counseling on a similar topic are invited to the therapy process in } \\
\text { support of the newly formed story. }\end{array}$ \\
\hline
\end{tabular}


related to their duties, placing emphasis on confidentiality. Therapists should attempt to establish therapeutic cooperation between themselves and the couple/family members (McNicholas, 2018). Table 1 explains the narrative therapy process.

\section{The Task of the Therapist in Narrative Couples and Family Therapy}

Instead of focusing on using measurement tools that assess the couples'/family's relations in a two-dimensional and superficial way (i.e., healthy and unhealthy) in this therapy approach, the narrative therapist gives importance in the therapy to how people like the narrative they live, to how these stories contain meanings and events that don't harm other people, and to the idea that each relationship can be experienced and conveyed in its own reality. The task of the therapist in the consultation process is to ask questions that will enable the couple/family members to think about the effects the problem has on their lives, its effects on their spouse's/other family members' lives, how it affects their relationships, and what kind of attitudes they can assume regarding the problem. The therapist attempts to develop awareness of problematic discourses in the therapy, and the opportunity to define and evaluate the effects these discourses have on the relationships is offered to the couple/family members (Freedman \& Combs, 2008). In narrative couples/family therapy, the therapist is a guide who establishes equal relations based on cooperation. The clients are the experts on their lives. The therapist helps couples and families restructure their stories, assuming the role of coauthor in the clients' narratives. In the counseling process, the therapist actively forms knowledge with the clients, supports the clients in restructuring the information they created, and facilitates the healing process (Morgan, 2000; Yeni, 2014).

Therapists have ethical rules they must adhere to in the therapy process. These rules can be listed as: being autonomous, doing no harm, being useful, being fair among the clients, having professional competence, keeping one's promises, and being honest (American Counseling Association, 2014; Camadan, 2018). Aside from the existing ethical rules, other ethical conditions are also found that therapists need to consider when applying spiritually oriented therapy. In therapy practices that contain religious or spiritual elements, therapists must avoid imposing their own values on clients, respect everyone's beliefs or spiritual views they possess, and implement these practices with the clients' consent and within the field of the therapist's competence (Shafranske, 2013). Additionally, having therapists who implement spiritually oriented counseling receive supervision (the portion of the therapist's discovery is removed) can contribute to them feeling more relaxed and comfortable on these issues in the consultation process. The clients' spiritual worldview being accepted by the therapist assists in developing the clients' sense of trust. Having spiritually oriented clients be able to talk with the therapist about spiritual issues can be beneficial for them (Post \& Wade, 2009). 


\section{Narrative Therapy and Spirituality}

Spirituality can be defined as the thoughts, feelings, and behaviors of a person that aim at establishing a relationship with what is sacred (Summertime, 2017). In an interview in 2000 with Michael White, one of the founders of narrative therapy, he stated spirituality to be an element contained in and shaping life. He stated that spirituality at the same time has three types: immanent, ascendant, and immanentascendant. While the immanent dimension of spirituality expresses a process of reflecting the true essence of the individual, the ascendant dimension expresses the type of spirituality that takes place at higher levels beyond daily life. Immanentascendant spirituality is defined as the process of getting in touch with an inner or divine experience that emerges by combining the two types and establishing a relationship with the exalted one God that exists in the depths of the person. White (2000) emphasized the external spirituality that has visibility in human life and helps people get to know themselves better rather than a sacred or divinity-centered understanding of spirituality.

Being one of the elements contained in and shaping life, spirituality's use in therapy provides advantages in cases requiring spirituality to be benefitted from as a psychological resource and the field of spirituality to be preserved, nourished, or developed and in situations where the spiritual search is necessary in terms of the individual (Ekşi, Kaya, \& Çiftçi, 2016). Including spirituality in the psychological counseling process allows the couple/family to be addressed from a holistic point of view by taking their beliefs, values, feelings, and thoughts into consideration (Frame, 2003). In Carlson, Fitzpatrick, Hecker, and Killmer's (2002) research, two out of three people receiving marriage and family therapy education voiced spirituality to be an element that needs to be addressed in the psychological counseling process; this reveals how important the concept can be for couples and families. Narrative therapy's nature in regard to taking the culture, beliefs, and spiritual values that shape clients' narratives into consideration (Yalın, 2017) shows that this approach can be used in a way that will cover spirituality in counseling with regard to couples and families (McNicholas, 2018). From this perspective, centering on people's story in narrative therapy allows them to express themselves by also including spirituality, which is one of the elements that shape the stories of spiritually oriented clients, and these clients are able to convey their relationship with a sacred power in the therapy environment (McWeigh, 2016; Truter \& Kodze, 2005).

In narrative therapy, individuals are suggested to understand through the mediation of stories that they form their lives (Madigan, 2016). Spirituality also plays an active role in the process of make sense of life as a part of couples' and families' stories (Dennett, 1992). Spirituality and narratives form the basis of one's self-perceptions by serving as a bridge between the past and future and shaping who the individual is (Baldwin \& 
Estey, 2015). In narrative therapy, when considering that people understand themselves and others by way of the relationships that are born and established in the world of written stories, spirituality and the relationship established with God are contained in the stories of individuals that overlap one another (Baldwin \& Estey, 2015).

From this perspective, including the dimension of spirituality that clients possess in the therapy process is important while working with spiritually oriented clients. Aside from narrative therapy techniques, the use spiritual and religious stories in the therapy process assists spiritually oriented clients in gaining hope and courage about the future (Coyle, 2010). Stories with spiritual content play a functional role in forming alternative narrations. For example, the process that led to a speech against the political and traditional order of that day by liberating Prophet Moses from the self-limiting narrative about the speech difficulties he experienced shows sacred texts to contain many stories that challenge the dominant narratives (Morningstar, 2010). In the same way, using the stories mentioned in the Qur'an related to the prophets and the tribes that had lived previously as a metaphor may offer individuals alternative perspectives on their lives, enable them to see the values that empower them, and plays a role in defining their beliefs and identities (Dumlu, 2006).

In addition to these, spirituality guides parents in their relationship with their children as a concept that hosts ethical and moral elements and can be a powerful resource spiritually oriented parents can use to cope with the difficulties they face (Dollahite, Slife, \& Hawkins, 1998). Dollahite, Marks, and Olsonm (2002) stated that spiritually oriented fathers can used spirituality as a source of power in the problems they encounter related to fatherhood; the case study they shared related to the use of spirituality as a source of power in the study they performed is as follows:

Michael's son Alan was born with arms shorter than normal, fingerless hands, and a spinal curvature that required many surgeries. Michael started questioning the purpose of life after his son was born. During the questioning he began to consider that beauty was not about physical appearance but about the quality of the heart and soul. During the meetings he made with doctors from different parts of the country for Alan, Michael saw that people approached his son kindly and unselfishly, and his son had revealed the love, goodwill, and divine side contained in people. When considering what is really important in life, Michael realized that piety was the most important factor in life. He began seeing his son as a gift from God. He gave an example of this situation by relating a memory he'd experienced with his son. "Alan and I were alone in the kitchen, and while looking at me he said 'If I were born again I would like to have hands like Kathleen and Benjamin.' For a moment, I didn't say anything, it was just a short pause, and then he said, 'But these hands are the challenges that God gave me for this life.' Then enthusiastically and heartily he said, 'It's no problem, this is my struggle in life." "Michael began to see fatherhood as an eternal relationship with his son, thanks to his religion and faith. He said that the eternal perspective had helped him see his son Alan differently and more positively. In addition, the perspective of eternity helped his son Alan see his physical condition as a limitation and challenge just for this world. The case 
on Michael's journey of fatherhood as a religious individual helped him see more positively the events and situations of being strong spiritually by focusing on his son's "non-physical" abilities, his heart and soul, rather than his physical limitations.

As seen, spirituality can positively impact parents' life narratives, can assist them in coping with the problems they have with their children, and comes across as an element that shapes the stories of spiritually oriented couples/families. From this perspective, spirituality will continue to have a significant place both in daily life and in the consultation process as long as it relates to people's relationships, identities, and form of existence (McWeigh, 2016).

\section{The Techniques of Narrative Couples/Family Therapy and Spirituality}

Presenting a framework that allows spirituality to be incorporated into narrative therapy (Yalın, 2017) provides the possibility for using it while working with spiritually oriented clients by including spiritual elements in the narrative couples/ family therapy's techniques (McNicholas, 2018). How spiritual elements can be used in this context by including them in the narrative therapy techniques while working with spiritually oriented couples or families is explained below.

1) Asking questions. With each question in the therapy interactive conversations that push individuals to think and question are attempted to be made. From this perspective, questions are asked for the purpose of having couples/family members gain new perspectives (Freedman \& Combs, 1996). Because people and relationships are not considered to have fixed and measurable characteristics, narrative couples and family therapy makes no assessments for collecting information in this direction. People's lives are seen as multiple stories, and each new narrative aims to be heard in certain contexts with the idea that discourse creates new meanings. Asking questions aims at evaluating the couples'/family members' problems and the connections their relationships have with the problem. In the therapy, couples/family members are asked to assess current situations, give names to the problems, evaluate their relationships' connection with the problem, assume an attitude toward the relationship and problem, give voice to more satisfying stories about their relationships, and to assess the utility of their alternative stories. Some questions that may be asked in this context are presented below (Freedman \& Combs, 2008):

- What name do you give the problem?

- How has the problem changed the relationship you have with yourself?

- Is this what you want for your relationship? If yes, why, if no, why not?

- Are we talking about the topics you want to talk about?

- Is the dialogue between us beneficial for you? If so, how is it benefitting you? 
Questions with spiritual content may also be asked in order to see the impact of spiritual elements in the life stories of spiritually oriented couples/family members and to see what things provide meaning and purpose in the clients' lives. In this context, the following are questions that may be asked in this respect (McWeight, 2016):

- How does your faith impact the situation you have with the problem?

- From which aspects does your faith provide support in coping with the problem?

- What effects does having this belief have on your daily life?

- How have the spiritual behaviors in your life contributed to you overcoming your difficult times?

- What are the things that are important to you while trying to deal with the problems you've mentioned?

- Which values are shaping your decisions?

2) Externalizing conversations. The externalization technique is a reflection of the understanding that "The person is not the problem, the problem is the problem," which is the motto of narrative therapy (Gehart, 2014; White \& Epston, 1990). Being alive doesn't require integrating with problems; living life is related to problems. For this reason, instead of seeing people who come to therapy as problematic people, seeing them as individuals under the influence of the problem hinders people from being needlessly labeled. From this perspective, the process of externalization includes deteriorating the power structure that the dominant story has, distinguishing the problem from the couple/family members who have identified themselves with the problem, and sometimes giving a name to this problem. Having the client talk about themselves in the third person makes the problem better understood and analyzed. In this way, the couple/family members stop trying to blame each other or change the person who has been identified as problematic; the person, spouse, or family are able to collaborate with the therapist as a team against the problem (Beckenbach, Patrick, Sells, \& Terrazas: 2014; Corey, 2008; Madigan, 2016; McNicholas, 2018; Suddeath et al., 2017; White, 1988; Yeni, 2014).

Asking externalizing questions related to the contextual effects regarding the problem exposes the dominant discourses. The questions asked invite people to think of how all the contexts of their lives impact the problem. As a result of an externalizing interview, both the couple/family members are seen to have relationships with the problem they've named as well as focus on the effects the impact of the problem has over their lives and relationships. Externalizing the problem from the couple/family members in this way allows them to come together and act as one against the effects 
of the problem (Nichols, 2013). In this context the following questions may be used for externalizing the problem (Freedman \& Combs, 2008):

- What name have you given the problem?

- What is it like to experience the problem?

- What are the effects the problem has had in your lives?

- What effects has the problem had on your relationship with one another?

- How has the problem changed the relationship you have with yourself?

The problems experienced in marriage that can be evaluated in the context of sin may also be assessed as spiritual struggles within the externalizing conversations. McNicholas (2018) argued that the relationship Prophet David in the Bible had with Bathsheba and the shame he experienced after breaking the compromise he'd made with God could be given as an example of the use of spiritual elements in the externalization technique. The questions that can be asked in this context are as follows:

- What did "lust" do to David?

- How did "lust" persuade David to find excuses for his sins?

- How did David lose his understanding of "right and wrong" due to "lust"?

- Where was lust found while David sat in great embarrassment after being left alone in the world by God?

3) Finding unique outcomes. Unique outcomes are finding the times and moments where the problem people have identified was not experienced or experienced less (Gallant \& Strauss, 2011). Unique outcomes can be in the form of a plan, action, emotion, statement, desire, dream, thought, belief, ability, or commitment (Morgan, 2000). Sometimes the clients offer unique outcomes directly. For example, someone who describes a problem by way of sentences like "It wasn't always like this, occasionally...," reveals unique outcomes. Other times the unique outcomes seem to have been lost in people's problematic stories, and listening to them carefully is necessary to find the unique outcomes. The clients are asked questions to find the unique outcomes. When making a detailed investigation on the effects the problem has over people, they can generally find examples where they are able to avoid the effect of the problem (Freedman \& Combs, 2008). In this context, the following sample questions can be asked (Madigan, 2016; Nichols, 2013; Rosen \& Lang):

- Were there times when "sadness" was less effective in your relationship? What was different in those times? 
- Were there times when your daughter didn't listen to the lies "anorexia" told her about her body?

- What do you think is able to support your hope that will help you avoid "worry"?

When using this technique in terms of spirituality and religion, the therapist can listen to the couple's/family members' pain and negativity that occurs in their narrative by considering God's existence and transformative power and focus on finding unique outcomes. Listening to unique outcomes contributes to sprouting hope for people who have the belief that a God exists who will relieve their pain in the hardest times. Belief that senses the presence of a divine power is able to transform the difficulties and storms in a relationship into alternative narratives because of unique outcomes through the mediation of courage and endurance (Alexander, 2008). Through the mediation of unique outcomes, couples/family members are also able to see the moments of grace. From this perspective, the therapist can use religious stories and sacred texts in order to help the couple/family members arrive at the awareness of the moments of grace. For example, in Christian beliefs, God is considered to be the one who sees and creates the stories couples' prefer. From this perspective, the therapist may want the couple to imagine what God sees for them before beginning more relationships. Additionally, the therapist may prepare the groundwork for finding unique outcomes by asking them as a couple about what kind of plan could exist on the point of serving society and their family (Alexander, Silver, \& Brown, 2008).

4) Finding the Absent but Implicit in the Narrative. Michael White (2000) stated that listening to the goals, values, hopes, and commitments that are absent but implicit in people's narratives can be very beneficial. Using White's double listening technique when listening to problematic stories reveals what the couple/family members give value to in the relationship. For example, by applying the double listening technique to a female client who externalized as "betrayal" the problem she'd experienced in her relationship, the concept of "trust" can be focused on, which was not mentioned in her story but is important to her (Freedman \& Combs, 2008).

When addressed spiritually, the therapist can approach a person's emotions such as pain or anger while using this technique with the thought that under these emotions is often a value that the other spouse/family members have violated. The therapist listens to clients with the hope and belief of discovering the implicit message that exists behind what the clients are narrating. If the therapist addresses with patience the negative feelings the couple/family members have, the therapist can discover the value that this emotion is related to (Alexander et al., 2008).

5) Speaking and Witnessing. Narrative therapy aims to cut destructive communication cycles by enabling the couple/family members to remain psychologically connected to 
each other (Wong, 2014). Narrative couples therapy helps people in regard to listening in a way where spouses will be able to hear new and appreciable things in each other's stories. When a spouse is asked to witness the other spouse's story, the hope is that they will listen and address the story being narrated from a different perspective. Using this technique requires the client's approval. While using this technique, in addition to the position of witness where one spouse listens to the other, therapists also may participate in the counseling as foreign witness groups as a part of training or education. Another way to use the technique may be to invite another couple (who have experience dealing with a specific issue) to the counseling as outside witnesses or to have people who are significant in the lives of the couple participate as outside witnesses (Freedman \& Combs, 2008; Rosen \& Lang, 2005).

While applying the technique, one of the spouses is asked to narrate the story and the other is asked to listen in the witness position to that is said. After narrating a story, the other spouse is expected to echo what he/she heard in the witness position. Later on, the narrator re-reflects from her/his own perspective the spouse's reflections on what he/she had heard. Then the one in the witness position invites the spouse to tell the story from his/her own perspective. While working with couples, another method that can be used for initiating the narrative and witness positions is listening with an original point of view. The therapist asks the couple to think of someone whom they value in their lives and who they feel hears and understands them when this person listens to them. For example, the therapist told the male client to think of a friend who showed him respect and is a good listener, and then the therapist asks him to listen to his partner like his friend listens to him. This allows clients to listen to their spouse from a different perspective (Freedman, 2014).

McNicholas (2018) suggests that, when this technique is wanted to be used spiritually, the therapist can invite the spouses to identify religious stories and religious people who are impactful on the point of understanding, accepting, and being merciful to one another; the therapist will be able to place the spouses in the witness position by listening like these religious figures.

6) Reincorporating conversation. The concept of reincorporation is related to the important people in one's history, to those who are currently important in one's life, or to people who are potentially important. It is about the affiliations in life and how these affiliations intertwine (White, 2007). Using the "club of life" metaphor, narrative therapy suggests that everyone is able to choose the people who contribute to being the person they want to be as a member of the club of life (Tarragona, 2008). These people are people who play a role in shaping the individual's personality and are respected members of the club of life. Seeing life as a club formed of members opens up new areas in the therapy on updating or reorganizing memberships. Determining 
the other people who will be informed about this alternative story that forms about the identity of individuals is attempted by asking reincorporating questions (Gerhart, 2014; Morgan, 2000; Russel \& Carey, 2002, as cited in Koca, 2018).

In the belief of Christianity, God is in the position of knowing more about all aspects of the client's life than the client him/herself (Alexander et al., 2008). For a Christian individual, God is the most important member of the "club of life," and the identity of Christianity is created in this relationship. The person's story is not written just by individual self, it is always written within the relationship one has with God. From this perspective, the understanding exists in Christianity that God is the one who knows sadness, sorrow, betrayal, and death and transforms these to a story of love, grace, joy, and life; for the couples and families, God will remain as the most important "club of life" member (Alexander et al., 2008).

\section{Results}

Narrative therapy, which was formed by Michael K. White and Davi Epston in the 1980 s, emerged as a form of the social constructivist approach, which has postmodernist foundations (Polkinghorne, 2000). According to narrative therapy, reality is formed by multiple stories and constructed socially. People gain identity in the social circle within which they are found; they maintain their existence and psychological health by means of those around them. People shape their stories through social factors (e.g., family structure, religion, culture); these stories transform in time into the dominant narrative and form their perception of self. The intention in narrative therapy is to form alternative stories in place of the dominant discourses that harm the client (Kararmak \& Bugay, 2016; Morgan, 2000; White \& Epston, 1990).

Narrative therapy places the clients' story at the center of the client, providing the opportunity for clients to be able to explain themselves inclusive of their spirituality, which is one of the elements shaping the lives of spiritually oriented clients, and to convey the relationships they have with a sacred power in the therapy environment. Michael White advocates spirituality to be a part of life and to shape life, and he stated that spirituality can have different forms. White takes the apparent spirituality as the point of focus instead of the unseen sense of sacred spirituality and adopts this spiritual approach that is visible in human life and allows one to better know the self. Spirituality is a part of the story, and discovering one's spiritual self occurs through stories. Additionally, spirituality also plays an important role in how people gain their identity (McWeigh, 2016; Truter \& Kodze, 2005; White, 2000).

The best-known techniques of narrative therapy are asking questions, externalizing conversations, finding unique outcomes, finding the absent but implicit in the narrative, speaking and witnessing, developing stories from the unique outcomes, 
and reincorporating conversations (Freedman \& Combs, 2008). By adding spiritual elements to the techniques of narrative therapy, the techniques can be used while working together with spiritually oriented couples and families (McNicholas, 2018).

When examining the literature outside of Turkey, the inclusion of spiritual elements is seen used in narrative therapy while working with spiritually oriented clients, and studies are found that reveal narrative therapy used by including spiritual elements to have a positive effect on solving the problems of spiritually oriented individuals, couples, and families (Baldwin \& Estey, 2015; Bermúdez \& Bermúdez, 2002; De Beer \& Müller, 2009; De La Lama \& De La Lama, 2011; Kropf \& Tandy, 1998; Marais, 2009; McNicholas, 2018; McWeigh, 2016; Morningstar 2010; Robbins, 2014).

When examining the literature in Turkey, no study apart from the book chapter "Manevi Öyküsel Terapi" [Spiritual Narrative Therapy] by Yalın (2017) is found that addresses narrative therapy from the perspective of spirituality. Additionally, a limited number of studies are found addressing narrative couples/family therapy in the literature in Turkey. Aside from these, no other study is found to have been performed in Turkey related to the use of spiritual elements in narrative couples/ family therapy, and this situation constitutes a major gap in the literature. From this perspective, the current study is believed to fill a significant gap in the field due to both their being no study related to the use of spirituality in narrative couples/family therapy as well as the research and theoretical knowledge on narrative couples/family therapy being limited. This study's examination of the use of narrative couples/family therapy by including spiritual elements is thought to provide a different perspective to practitioners and researchers in the field and to form the basis for future research.

The use of narrative therapy with spiritually oriented couples and families has mostly been conducted outside of Turkey based on the Christian perspective and by benefitting from the Bible or Torah (Morningstar 2010). Starting with the research and practices that took place in this study outside of Turkey where spiritual elements were included in the narrative therapy, narrative therapy practices where spirituality is included based on the teaching of the Islamic religion by benefitting from the Qur'an in accordance with Turkish culture can be used while working with spiritually oriented couples and families. Researchers in the future can conduct experimental studies that test the effect of narrative couples/family therapy practices where spirituality has been included in accordance with the culture and belief system of Turkey. In order to implement these recommendations, therapists can be given informative trainings on religious-spiritual matters in addition to their therapy education. In this way, therapist can be allowed to provide a more comprehensive consultation by way of understanding spiritually oriented clients' religious backgrounds and belief systems. 


\section{Acknowledgement}

This article does not involve any human participant data, and thus no ethical approval was required.

\section{References}

Akdemir, A., Karaoğlan, A., \& Karakaş, G. (2006). Çift terapisi [Couples therapy]. Türkiye'de Psikiyatri, 8(2), 123-128.

Alexander, I. (2008). Narrative, suffering and the alternate story. In R. Cook \& I. Alexander (Eds.), Interweavings: Conversations between narrative therapy and Christian faith (pp. 114-125). North Charleston, SC: CreateSpace Books.

Alexander, I., Silver, J., \& Brown, J. (2008). Narrative ideas and practices in pastoral care and counseling. In R. Cook \& I. Alexander (Eds.), Interweavings: Conversations between narrative therapy and Christian faith. North Charleston, SC: CreateSpace Books.

American Counseling Association. (2014). Amerikan psikolojik danışma derneği etik kodları. Alexandria, VA: Author.

Baldwin, C., \& Estey, J. (2015). The self and spirituality: Overcoming narrative loss in aging. Journal of Religion \& Spirituality in Social Work: Social Thought, 34(2), 205-222.

Beckenbach, J., Patrick, S., Sells, J., \& Terrazas, L. (2014). The statement of us: A narrative-based practice for enhancing couples' preferred identity. Journal of Systemic Therapies, 33(2), 50-61.

Bermúdez, J. M., \& Bermúdez, S. (2002). Altar-making with Latino families: A narrative therapy perspective. Journal of family psychotherapy, 13(3-4), 329-347.

Besa, D. (1994). Evaluating narrative family therapy using single-system research designs. Research on Social Work Practice, 4(3), 309-325.

Brown, C., \& Augusta-Scott, T. (2007). Narrative therapy: Meaning making, making lives. Thousand Oaks, CA: Sage.

Camadan, F. (2018). Psikolojik danışmanın yaşadığı çatışma: Etik ikilem [Conflict experienced by the psychological counselor: Ethical dilemma]. Sakarya University Journal of Education, 8(1), 76-94.

Carlson, T., Fitzpatrick, D., Hecker, L., \& Killmer, J. M. (2002). Religion, spirituality, and marriage and family therapy: A study of family therapists' beliefs about the appropriateness of addressing religious and spiritual issues in therapy. The American Journal of Family Therapy, 30, 157-171.

Carr, A. (1998). Michael White's narrative therapy. Contemporary Family Therapy, 20(4), 485-503.

Corey, G. (2008). Psikolojik danışma, psikoterapi kuram ve uygulamaları. Ankara, Turkey: Mentis Yayınc1lik.

Coyle, S. (2009). Spiritual narratives: Hope and healing through stories of faith. In J. H. Ellens (Ed.), The healing power of spirituality: How faith helps humans thrive (pp. 189-201). Santa Barbara, CA: ABC-CLIO.

Crocket, K. (2013). Narrative therapy. In J. Frew \& M. D. Spiegler(Eds.), Contemporary psychotherapies for a diverse world (pp. 459-500). New York, NY: Routledge/Taylor \& Francis Group.

Dallos, R. (2006). Attachment narrative therapy: Integrating systemic, narrative and attachment approaches. New York, NY: Open University Press.

De Beer, S., \& Müller, J. (2009). Using stories to assist storytelling in a pastoral setting: Four female pastors in dialogue with Mary Magdalene. HTS Teologiese Studies/Theological Studies, 65(1). 
De La Lama, L. B., \& De La Lama, L. (2011). Counseling a terminally ill agnostic seeking to reclaim spirituality: A narrative approach to dying well. Retrieved from http://counselingoutfitters.com/ vistas/vistas11/Article_103.pdf.

DeMille, S. M., \& Montgomery, M. (2016). Integrating narrative family therapy in an outdoor behavioral healthcare program: A case study. Contemporary Family Therapy, 38(1), 3-13.

Dennett, D. C. (1992). The self as the center of narrative gravity. In F. Kessel, P. Cole, \& D. Johnson (Eds.), Self and consciousness: Multiple perspectives (pp. 103-115). Hillsdale, NJ: Lawrence Erlbaum.

Dollahite, D. C., Marks, L. D., \& Olsonm, M. M. (2002). Fathering, faith, and family therapy: Generative narrative therapy with religious fathers. Journal of Family Psychotherapy, 13(3-4), 259-289.

Dollahite, D. C., Slife, B. D., \& Hawkins, A. J. (1998). Family generativity and generative counseling: Helping families keep faith with the next generation. In D. P. McAdams \& E. de St. Aubin (Eds.), Generativity and adult development: How and why we care for the next generation (pp. 449-481). Washington, DC: American Psychological Association.

Duba, J. D., Kindsvatter, A., \& Lara, T. (2008). Treating infidelity: Considering narratives of attachment. Family Journal, 16, 293-299.

Dumlu, Ö. (2006). Kur'an'da kıssa [Parables in the Qur'an]. In M. Aydın \& Ö. Dumlu (Eds.), Ana Konulartyla Kur'an [Major themes of the Qur'an] (15th unit). Eskişehir, Turkey: Anadolu Üniversitesi Açıköğretim Fakültesi Yayını.

Ekşi, H., Kaya, Ç., \& Çiftçi, M. (2016). Maneviyat ve psikolojik danışma [Spirituality and psychological counseling]. In H. Ekşi \& Ç. Kaya (Eds.), Manevi yönelimli psikoterapi ve psikolojik danışma [Spiritually oriented psychotherapy and psychological counseling] (pp. 1127). İstanbul, Turkey: Kaknüs Yayınları.

Epston, D., \& White, M. (1992). Experience, contradiction, narrative \& imagination: Selected papers of David Epston \& Michael White, 1989-1991. Adelaide, Australia: Dulwich Centre Publications.

Fraenkel, P., Hameline, T., \& Shannon, M. (2009). Narrative and collaborative practices in work with families that are homeless. Journal of Marital and Family Therapy, 35(3), 325-342.

Frame, M. W. (2003). Integrating religion and spirituality into counseling: A comprehensive approach. Pacific Grove, CA: Brooks/Cole

Freedman, J. (2014). Witnessing and positioning: Structuring narrative therapy with families and couples. Australian and New Zealand Journal of Family Therapy, 35, 20-30.

Freedman, J., \& Combs, G. (1996). Shifting paradigms: From systems to stories. In Narrative therapy: The social construction of preferred realities (pp. 1-18).

Freedman, J., \& Combs, G. (2008). Narrative couple therapy. In A. S. Gurman, J. L. Lebow \& D. K. Snyder (Eds.), Clinical handbook of couple therapy (pp. 229-258). New York, NY: Guilford Press.

Gallant, P., \& Strauss, I. (2011). Narrative therapy with couples. In D. K. Carson \& M. CasadoKehoe (Eds.), Case studies in couples therapy: Theory-based approaches (pp. 289-301). New York, NY: Routledge.

Gehart, D. (2014). Mastering competencies in family therapy: A practical approach to theories and clinical case documentation. Belmont, CA: Brooks/Cole

Gladding, S. (2012). Aile terapisi: Tarihi kuram ve uygulamaları [Family therapy: History, theory, and practice] (I. Keklik \& İ. Yıldırım, Trans.). Ankara, Turkey: PDR Yayınlar.

Gold, J. M. (2016). Stepping in, stepping out: Creating stepfamily rhythm. Alexandria, VA: American Counseling Association. 
Karaırmak, Ö., \& Bugay, A. (2016). Postmodern diyalog: Narrative psikolojik danışma [Postmodern dialogue: Narrative psychological counseling]. Türk Psikolojik Danışma ve Rehberlik Dergisi, 4(33).

Koca, M. (2018). Narrative terapi temelli grupla psikolojik danışma programının ergenlerin irade ve kayg d düzeylerine etkisi [The impact of narrative therapy-based group psychological counseling program on youths' self-control and anxiety levels] (Unpublished master's thesis). Hasan Kalyoncu Üniversitesi, Sosyal Bilimler Enstitüsü, Gaziantep, Turkey.

Kropf, N. P., \& Tandy, C. (1998). Narrative therapy with older clients: The use of a "meaningmaking” approach. Clinical Gerontologist, 18(4), 3-16.

Madigan, S. (2016). Naratif terapi (G. Akkaya, Tran.). İstanbul, Turkey: OkuyanUs Yayınevi.

Marais, J. C. (2006). (Re)-constructing a life-giving spirituality: narrative therapy with university students (unpublished doctoral dissertation). University of South Africa, Pretoria.

McNicholas, G. T. (2018). Toward a narrative approach to Christian marital therapy (unpublished doctoral dissertation). The Divine Mercy University, Institute For The Psychological Sciences.

McWeigh, A. K. (2016). Spirituality in practice: An exploration into narrative practitioners' approaches to addressing spirituality in counselling practices (unpublished master's thesis). UNITEC, New Zealand.

Morgan, A. (2000). What is Narrative Therapy? Australia: Dulwich Centre Publications.

Morningstar, B. I. (2010). Stories that transform: Narrative approaches to spiritually oriented clinical practice. Smith College Studies in Social Work, 80(2,3), 286-303.

Nichols, M. P. (2013). Aile terapisi: Kavramlar ve yöntemler [Family therapy: Concepts and methods] (O. Gündüz, Tran.). İstanbul, Turkey: Kaknüs Yayınları.

Payne, M. (2006). Narrative therapy: An introduction for counsellor. London, UK: Sage Publications.

Polkinghorne, D. E. (2000). Narrative theraphy. In A. E. Kazdin(Ed.), Encychopeida of psychologhy. Oxford, UK: Oxford University Press.

Post, B. C., \& Wade, N. G. (2009). Religion and spirituality in psychotherapy: A practice-friendly review of research. Journal of Clinical Psychology, 65(2), 131-146.

Robbins, C. (2014). Wesleyan narrative pastoral conversations: coauthoring the parishioner's story through Wesleyan theology, narrative therapy, and pastoral counseling. Asbury Theological Seminary, Asbury, KY: USA.

Rosen, L. V., \& Lang, C. (2005). Narrative therapy with couples: Promoting liberation from constraining influences. In M. Harway (Ed.), Handbook of couples therapy (pp. 157-178). Hoboken, NJ: Wiley.

Saltzburg, S. (2007). Narrative therapy pathways for reauthoring with parents of adolescents comingout as lesbian, gay, and bisexual. Contemporary Family Therapy: An International Journal, 29, 57-69.

Shafranske, E. P. (2013). Klinik psikoloji ve danışmanlık psikolojisinde din psikolojisi [Religious psychology in clinical and counseling psychologies] (S. Turan Tran.). In R. F. Paloutzian \& C. L. Park (Eds.). Din ve maneviyat psikolojisi [The psychology of religion and spirituality] (pp. 409-442). Ankara, Turkey: Phoenix Yayınevi.

Samanc1, A. Y., \& Ekici, G. (1998). Aile terapisi [Family therapy]. Düşünen Adam, 11(3), 45-51.

Stokes, L. D., \& Poulsen, S. S. (2014). Narrative therapy for adoption issues in families, couples, and individuals: Rationale and approach. Journal of Family Psychotherapy, 25, 330-347. 
Suddeath, E. G., Kerwin, A. K., \& Dugger, S. M. (2017). Narrative family therapy: Practical techniques for more effective work with couples and families. Journal of Mental Health Counseling, 39(2), 116-131.

Summermatter, A. (2017). Bilişsel davranışçı terapiler ve maneviyat [Cognitive behavioal therapies and spirituality]. In E. Halil (Ed.), Psikoterapi ve psikolojik danışmada maneviyat: Kuramlar ve uygulamalar [Psychotherapy and spirituality in psychological counseling: Theories and practices] (pp. 87-115). İstanbul, Turkey: Kaknüs Yayınları.

Tarragona, M. (2008). Postmodern/poststructuralist therapy. In J. L. Lebow (Ed.), 21st century psychotherapies: Contemporary approaches to theory and practice (pp.167-205). Hoboken, NJ: John Wiley \& Sons, Inc.

Terzi, I. Ş., \& Tekinalp, B. E. (2013). Psikolojik danışmada güncel yaklaşımlar [Current approaches in psychological counseling]. Ankara, Turkey: Pegem Akademi.

Truter, C. J., \& Kotze, D. J. (2005). Spirituality and health: A narrative-pastoral approach. HTS: Theological Studies, 61(3), 973-984.

Vetere, A., \& Dowling, E. (2016) Narrative therapies with children and their families: A practitioners guide: Concepts and approaches. London, UK: Routledge.

White, J. D. (1992). Taking language seriously: Toward a narrative theory of knowledge for administrative research. The American Review of Public Administration, 22(2), 75-88.

White, M. (1988). The externalizing of the problem and the re-authoring of lives and relationships. Dulwich Centre Newsletter, 3-20.

White, M. (2000). Reflections on narrative practice: Essays and interviews. Adelaide, Australia: Dulwich Centre Publications.

White, M. (2007). Maps of narrative practice. New York, NY: Norton.

White, M., \& Epston, D. (1990). Narrative means to therapeutic ends. New York, NY: Norton.

Wong, P. T. P. (2014). Meaning in life. In A. C. Michalos (Ed.), Encyclopedia of quality of life and well-being research (pp. 3894-3898). New York, NY: Springer.

Yalın, H. S. (2017). Manevi öyküsel terapi. In E. Halil (Ed.), Psikoterapi ve psikolojik danışmada maneviyat: Kuramlar ve uygulamalar (pp. 189-209). İstanbul: Kaknüs Yayınları.

Yeni, G. K. (2014). Narrative terapi. In A. N. Canel (Ed.), Terapide yeni ufuklar: Modern, postmodern ve kısa terapiler (pp. 201-222). İstanbul: Pinhan Yayınc1lık. 